\title{
Mobile Phone Text Messaging Cross Platform Intervention for Cervical Cancer Screening: Changes in Knowledge and Attitude in Rural Areas Pre-Post Intervention
}

Niken Bayu Argaheni ${ }^{1}$, Firman F Wirakusumah², Maringan Diapari Lumban Tobing ${ }^{3}$, Herry Herman ${ }^{4}$, Deni K. Sunjaya ${ }^{5}$, Yudi Mulyana Hidayat ${ }^{6}$

${ }^{1}$ Department of Midwifery Universitas Sebelas Maret Jalan Ir. Sutami No.36, Kentingan, Kec. Jebres, Kota Surakarta, Jawa Tengah

2,3,6 Department of Obstetrics Gynecology Universitas Padjadjaran

${ }^{5}$ Department of Public Health Sciences Universitas Padjadjaran

${ }^{4}$ Department of Orthopaedic Universitas Padjadjaran

Jalan Raya Bandung Sumedang KM. 21, Hegarmanah, Kec. Jatinangor, Kab Sumedang, Jawa Barat

Email: kinantiniken@gmail.com

\begin{abstract}
Abstrak
Kunci keberhasilan program pengendalian kanker serviks adalah skrining diikuti dengan pengobatan yang memadai. Kesenjangan status sosial-ekonomi dan tingkat pendidikan yang rendah menyebabkan kesadaran dan pemahaman yang terbatas tentang wanita usia subur. Meningkatkan kapasitas pengetahuan wanita usia subur melalui pendidikan kesehatan baik secara langsung maupun tidak langsung adalah penting. Oleh karena itu, ada kebutuhan untuk mengembangkan pendidikan kesehatan dengan memanfaatkan media yang berkembang pesat saat ini seperti melalui penerapan pesan lintas platform pada smartphone. Penelitian ini bertujuan untuk menganalisis pengaruh penerapan pendidikan kesehatan pada deteksi kanker serviks melalui penerapan pesan lintas platform untuk meningkatkan pengetahuan dan sikap Wanita di Usia Subur. Penelitian quasi-eksperimental desain pre-post test dengan kelompok kontrol dilakukan yang terdiri dari 72 subjek. Fogg's Behavior Model adalah kerangka kerja konseptual yang memandu pengembangan intervensi perpesanan lintas platform. Serangkaian uji instrumen dari pakar dilakukan untuk pengembangan intervensi pengiriman pesan lintas platform. Pesan-pesan dikirim selama 7 hari di pagi hari. Pengumpulan data menggunakan instrumen daftar periksa. Analisis univariabel melalui Rasch dan pemodelan bivariabel menggunakan uji perbandingan kategori numerik, perbedaan menggunakan uji T. Temuan dari penelitian ini mengungkapkan peningkatan yang signifikan dalam pengetahuan dan sikap peserta skrining kanker serviks. Wanita Usia subur yang pendidikan kesehatannya melalui aplikasi lintas platform memiliki probabilitas 3,5 kali pengetahuan dan sikap yang baik dibandingkan dengan wanita usia subur yang tidak mendapatkan pendidikan kesehatan melalui aplikasi lintas platform. Pendidikan kesehatan melalui layanan perpesanan lintas platform dapat menjadi metode yang murah dan efektif untuk meningkatkan pengetahuan dan sikap wanita usia subur, serta menjangkau individu yang belum pernah melakukan deteksi dini kanker serviks.
\end{abstract}

Kata kunci : pendidikan kesehatan, wanita usia subur, aplikasi pesan lintas platform

Abstract

The key to the success of cervical cancer control programs is screening followed by adequate treatment. The socio-economic status gap and the low level of education lead to limited awareness and understanding of women of childbearing age. Increasing the capacity of knowledge of women of childbearing age through health education either directly or indirectly is important. Therefore, there is need to develop health education by 
utilizing the rapidly growing media today such as through the application of cross platform messages on smartphones. This study aims to analyze the effect of the application of health education on detection of cervical cancer through the application of cross-platform messages to increase knowledge and attitude of Women in Childbearing Age. A quasiexperimental research of pre-posttest design with control groups conducted consisting of 72 subjects of Women in Childbearing Age. Fogg's Behavior Model was the conceptual framework that guided the development of the cross-platform messaging intervention. $A$ series of checklist from expert panel conducted to inform the development of the crossplatform messaging intervention. The messages are delivered for a 7-day period in the morning. Data collection using a checklist instrument. Univariable analysis through Rasch and bivariable modeling using numerical categorical comparative test, difference using $T$ test. Findings revealed a significant increase in participants' knowledge and attitude of cervical cancer screening. Women of Childbearing Age whose health education through cross-platform application has a 3.5 times probability of knowledge and good attitude compared to women of childbearing age who are not getting health education through cross-platform applications. Health education through cross-platform messaging services can be a cheap and effective method to improve the knowledge and attitude of women of childbearing age, as well as reaching individuals who have never done early detection of cervical cancer.

Keywords: health education, women of child-bearing age, cross-platform messaging application

Article info:

Article submitted on 25 February 25, 2020

Articles revised on March 03, 2020

Articles received on May, 142020

DOI: http://dx.doi.org/10.21927/jnki.2020.8(2).123-133

\section{INTRODUCTION}

The World Health Organization (WHO) International Agency for Research on Cancer (IARC) estimated that there will be up to 21.7 million new cancer cases and 13 million cancerrelated deaths in 2030 , with $70 \%$ of those cases in Low To Middle-Income Countries (LMICs) (1-3). Globally, cervical cancer is the third most common cancer in women and impacts 275,000 women death each year which means a woman will die death by cervical cancer every two minutes(4). Changing lifestyles, increasing urbanization, changes in reproductive patterns and diet, obesity, tobacco-use, alcohol-drinking, chronic infection and increasing life spans contribute to an ever-increasing cancer burden and changing cancer pattern in Asian countries. Asian countries have extremely limited services and the cancer burden is substantial in these countries. Despite the growing burden of cancer, it remains a low priority in health care planning and expenditure in most Asian LMICs(5).

Cervical cancer is the second most common cancer among Indonesian women, after breast cancer (6). About 32,469 new cervical cancer cases are diagnosed annually in Indonesia (estimates for 2018)(7). In LMICs such as Indonesia, cancers are mostly diagnosed at an advanced stage, in which curative treatment is often no longer possible (8). Affordable cervical cancer screening is only available in eight of 34 provinces in Indonesia $(9,10)$. The low uptake may be attributable to a range of barriers including a lack of knowledge about cancer prevention as well as wide spread misconceptions and fears about cancer and its treatment(11). The psychological condition of a woman who has cancer at the beginning of a diagnosis and is 
declared positive as a cancer patient, then a sufferer will be very shocked and feel unbelief which can lead to feeling depressed, where sufferers feel anxious, stressed and depressed and angry and deny their illness because they have perceptions about life changes and how they can adjust. (12) In addition, there are often inequalities in the distribution of healthcare workers throughout the country, resulting inequalities in healthcare access especially between urban and rural areas.(13).

Patient, provider, and health system factors contribute to late diagnosis of cancer(14). Fears, stigma, limited cancer awareness and fatalistic beliefs $(15,16)$, male sex(17), spiritual and traditional beliefs (18) as well as low socio economic position and difficulty navigating the health system are notable patient related factors affecting delays in treatment. Health systems and provider factors include shortage of health-care providers, limited cancer knowledge and skills, (18) lack of diagnostic tools and technologies including pathology services(19), type of cancer(20), geographic distribution of services, and delayed referrals and poor coordination between facilities(15).

Organizing screening programs in developing countries where the greatest burden of cervical cancer has remained a challenge. There are many obstacles to cervical cancer screening in poor resource countries, generally attributed to a lack of infrastructure resources -technical, medical, and financial- and a lack of awareness and education about cervical cancer among women and healthcare providers. Moreover, in Africa and South America which bear the biggest cervical cancer burden, there are competing health care needs such as HIVIAIDS, infectious diseases such as malaria, tuberculosis, and high infant and maternal mortality rates. In addition there are not many trained clinicians, and there is a lack of adequate laboratory supplies, personnel and treatment facilities.(21).
Screening programs in resource-poor settings must consider these limitations and develop approaches sustainable and suitable for those settings such considering screening methods that target the etiologic agent HPV, appropriate age to initiates screening, and screening interval, and one designed to encompass screening and treatment at one time. (22). Rates of cervical cancer have plummeted in countries where cervical cancer screening has been implemented. Unfortunately, most developing countries lack resources for cervical cancer screening. This lack of screening results in the diagnosis of approximately 450,000 cervical cancer cases each year(23). As a result of lack of infrastructure and expense, cervical screening programs are unavailable in most developing settings and countries, and hence, declines in cervical cancer have not been observed in resource-poor countries and settings. Additionally, a constraint to screening in many developing countries is the cultural reticence to seek routine pelvic examination; even in some countries with established national screening protocols, women do not seek pelvic examinations and therefore often present with advanced disease $(5,24)$.

Visual inspection with acetic acid (VIA) is also known as direct visual inspection, or acetic acid test, is a very low-cost approach to screening that may be an option for areas that do not have access to comprehensive cervical cytological screening(25). VIA, at its most basic, consists of unmagnified evaluation of the uterine after the application of 3-5\% dilute acetic acid for visual signs of a high-grade lesion or cancer. The test is considered positive if clear and welldefined acetowhite areas are detected near the squamous columnar junction (transformation zone). An advantage of VIA is that it gives immediate results, making it possible to treat abnormal lesions at the same visit.

Several cross-sectional studies, mostly performed in less-developed countries have 
evaluated VIA with mixed results. Sensitivity of VIA to detect high-grade lesions and cervical cancer have ranged from $49 \%$ to $96 \%$ and specificity from $49 \%$ to $98 \%(26,27)$. However, there were limitations to the studies. Most suffered from verification bias, first because the true disease status for a large majority of the individuals in the studies were not known; and second, most used colposcopy as the 'gold-standard' for disease verification, which is also been shown to have low sensitivity (28). However, VIA may prove to be a cost-effective approach to decrease cervical cancer incidence and mortality in countries with lack of resources that cannot afford a comprehensive cytological screening program.

Cervical cancer remains a critical public health problem. One of the most important methods of prevention of cervical cancer is early detection, which includes routine cervical screening. Evidence from a number of countries suggests factors high-lighted in most theoretical models for preventive behavior were related to cervical screening participation such as perceived effectiveness, perceived risk, perceived severity, and perceived barrier such as fear of embarrassment or pain (29). Effective health promotion strategies and educational programs addressing risk perception of cervical cancer and its relationship with cervical screening behavior among Indonesian women remain limited. Prior to any intervention on risk perception and subsequent screening uptake, a greater understanding of women's knowledge and perception of risk of cervical cancer and the role of personal risk factors is essential.(30). The emphasis of health promotion lies in the efforts of health education through newspapers, radio, television, leaflets, newsletters, magazines, posters, brochures and more. But the media is still limited its use. An alternative mass strategy is needed as an effective means of communication that has the potential to provide health information to the community on a difficult geographic so that it can reach and influence and motivate itself to learn and understand the health condition so as to be able to know the symptoms as early as possible through the utilization of cell phones (mobile phone)(31). This study aims to analyze the effect of the application of health education on detection of cervical cancer through the application of cross-platform messages to increase knowledge and attitude of Women in Childbearing Age.

\section{MATERIALS AND METHODS}

The Institutional Review Board of the Universitas Padjadjaran, the Advisory Panel on Ethics and Medico-Legal Affairs approved the study protocol prior to its implementation. A total of 72 women were enrolled, recruited from the rural community. No personal identifying information was collected in the anonymous questionnaire. All participants were given a full explanation of the methodology and purpose of the project and an assurance of confidentiality. A quasi experimental pre-posttest with control group design was used. Participants completed an interviewer-administered questionnaire on knowledge and attitudes concerning cervical cancer and cervical cancer screening. The intervention subject given a cross platform messaging service through WhatsApp application for 1 week. Source material taken from the website of the Ministry of Health of the Republic of Indonesia which is based on Fogg Behavior Model and conducted the content validity to the expert from Obstetrics Gynecologist, Midwife, Anthropologist, Communication Expert, Psychologist, Head of Prevention and Control of Non-Communicable Diseases Health Office of Pati Regency. The study was conducted in the Pati regency from May through August of 2016. Potential participants were defined as women aged 19 years and older. Information collected from participants through face-to-face 
interviews using a structured questionnaire administered at three time points: at the study enrollment (baseline), 1 week after completing the intervention (post-test)

Primary outcomes of interest included knowledge and attitudes about cervical cancer and cervical cancer screening. Knowledge scores are measured by a questionnaire adopted from Mahnoosh Khosravi (32). Knowledge of cervical cancer and early detection of lesions on the cervix were assessed based on 18 questions. Each correct answer is given a score of 1 and the wrong answer is given a score of 0 . Questions contain risk factors for cervical cancer, cervical cancer symptoms, prevention and treatment of frequency of early detection, and methods of early detection. Attitude is measured by the questionnaire adopted from Myriam Leyva. Attitude is measured by a Likert scale that includes indicators of belief in behavior, namely confidence not to be afraid of undergoing IVA tests, confidence that IVA tests need to be undertaken by women, confidence in IVA test results can be trusted, confidence in the duration of the IVA test examination and confidence in the benefits of IVA tests. The evaluation indicators for the consequences that will be covered consist of: the risk of IVA testing and the possibility of knowing abnormal results. With 13 questions, based on a Likert scale indicating negative and positive responses measured from strongly agree 5 , agree $=4$, neutral $/$ doubt $=3$, disagree $=$ 2 , strongly disagree $=1$. Information collected on sociodemographic characteristics of subject (e.g., age, marital status, education, employment status).

The analysis for testing the validity of the questionnaire instruments in this study uses Rasch modeling. What is seen is the level of validity of the response to the item based on the value of Outfit Means Square (MNSQ) the suitability of the middle squared value, Z-Standard Outfit (ZSTD), the suitability of the $\mathrm{z}$ test value, and Point Measure Correlation (Pt Mean Corr), namely the correlation between answers with an ideal model. The criteria used are as follows:

a. Outfit Mean Square (MNSQ) value received: $0.5<$ MNSQ $<1.5$

b. Outfit Z-Standard (ZSTD) value received: -2.0 $<$ ZSTD $<+2.0$

c. Point Measure Correlation (Pt Mean Corr) Value: $0.4<$ Pt Measure Corr $<0.85$

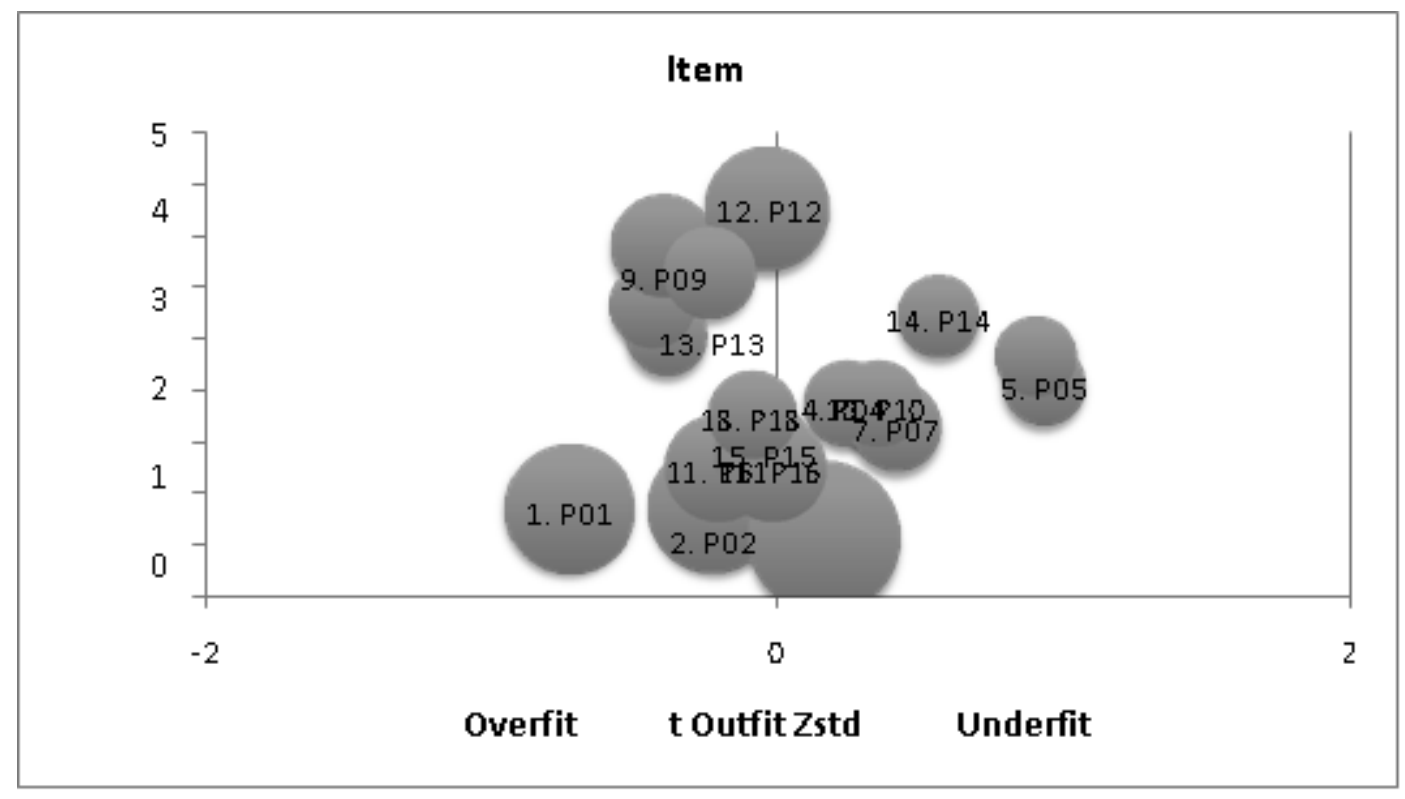

Figure 1. Bubble Chart of Knowledge Item Questionnaire 


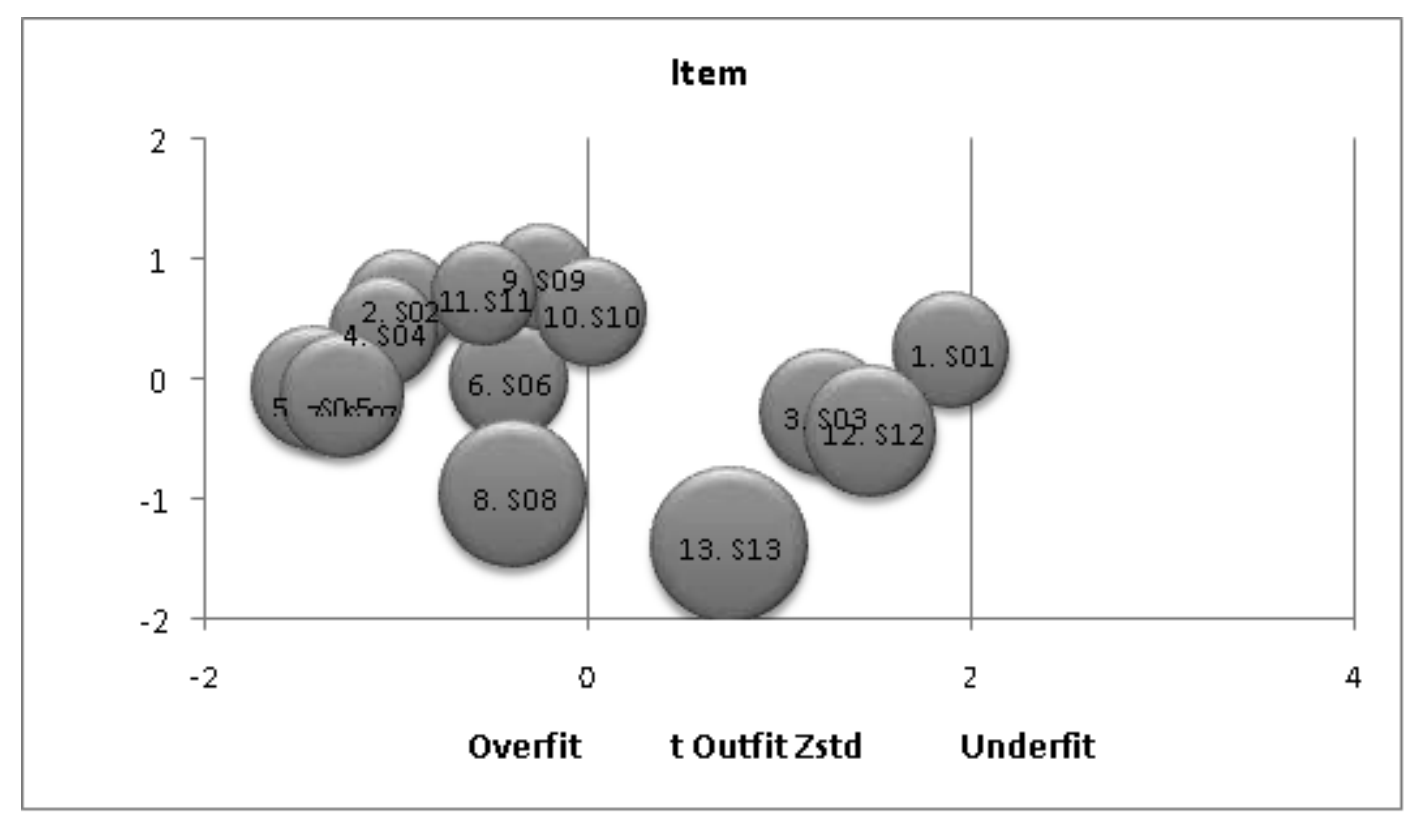

Figure 2 Bubble Chart Attitude Questionnaire

If the item items of the instrument meet at least one of the criteria above, the instrument can be used, in other words the item items are included as valid criteria in the answers given by the respondent. Validity test was carried out on 30 women of childbearing age in Margoyoso subdistrict, Pati Regency. The research instrument was tested on respondents who had the same characteristics as the study sample. According to Linacre (1994), a total sample of 30 people is eligible for a pilot test (pilot study), which is a range of accuracy levels at +1 logit with a $95 \%$ confidence level.(33).

There is the easiest item of knowledge to do, namely item number 3 , with the statement "Cervical cancer can be treated". The most difficult item to work on is item number 12, with the statement "IVA examination should be done at the age of 20 years."

There is an attitude item that is the easiest to do, namely in item number 13 , with the statement "I believe cervical cancer can be prevented through examination of cervical cancer with VIA". The most difficult item to do is item number 9 , with the statement "The results of early cervical cancer testing with VIA cannot be trusted because there are other better tests such as the pap smear test." Differences in constructs relating to knowledge, attitudes about cervical cancer and cervical cancer screening from baseline to 1 week-post-test were summarized by means and standard deviations, and tested using the paired t test.

\section{RESULT AND DISCUSSION}

Demographic Characteristics of the Sample

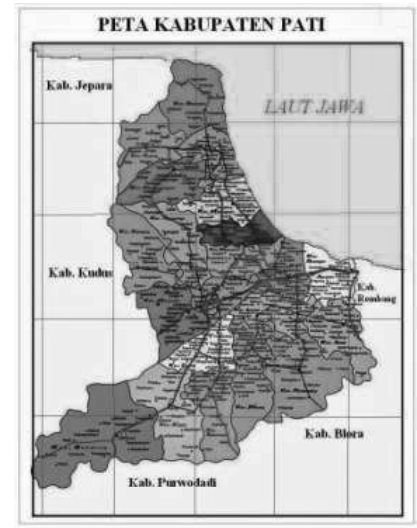

Figure 3. Maps of Research Location

Geographically, Pati Regency is located at coordinates: $6^{\circ} 44^{\prime} 56.80$ "LS - $111^{\circ}$ 02'06.96" East, with an area of $1,419.07 \mathrm{~km}^{2}$. Administratively, Pati Regency is bordered by 
the Java Sea in the north, Rembang Regency in the east, Blora Regency and Grobogan Regency in the south, and Kudus Regency and Jepara Regency in the west. Pati Regency has 21 Districts and consists of 405 villages. The study was conducted in one of the sub-districts in Pati, Margoyoso sub-district. Margoyoso District has 22 villages. The villages used in this study are Pohijo village and Tunjungrejo village.

Subject characteristics are shown in table 1. Mean age of these subjects of intervention and control groups was 35,33 years $(S D \pm 8,7)$ and $37,88(S D \pm 7,2)$. Most subjects had education length for 12 years or less. Most subject are married, have been giving a birth, and unemployed both in intervention or control groups.

Table 1. Baseline Sociodemographic Characteristics of The Sample

\begin{tabular}{lcc}
\hline \multicolumn{1}{c}{ Variable } & $\begin{array}{c}\text { Intervention } \\
\mathbf{n = 3 6}\end{array}$ & $\begin{array}{c}\text { Control } \\
\mathbf{n = 3 6}\end{array}$ \\
\cline { 2 - 3 } Age, years & $35,33( \pm 8,7)$ & $37,88( \pm 7,2)$ \\
Mean (SD) & 3 & 7 \\
\hline $\begin{array}{l}\text { Education } \\
\text { Graduates from } \\
\text { elementary School }\end{array}$ & & \\
$\quad \begin{array}{l}\text { Graduates from high } \\
\text { school }\end{array}$ & 29 & 26 \\
$\quad \begin{array}{l}\text { Graduated from college/ } \\
\text { university }\end{array}$ & 4 & 3 \\
\hline Parity & & \\
$\quad \begin{array}{l}\text { 1.Nullipara } \\
\text { 2.Primipara }\end{array}$ & 10 & 8 \\
$\quad$ 3.Multipara & 11 & 7 \\
\hline Marital status & 15 & 21 \\
$\quad$ Married & & \\
$\quad$ Other & 32 & 35 \\
\hline Employment & 4 & 1 \\
$\quad$ Yes & & \\
$\quad$ No & 4 & 51 \\
\hline
\end{tabular}

\section{Changes in Knowledge and Attitudes}

In the above table it is known that there is a significant difference in the score of posttest knowledge between the treatment group and the control group, the knowledge score between pre and posttest in the treatment group and the increase of pre and post test score in control group and treatment with $p$ value $<0.05$. Table 3 presents changes in measures of attitude comparing baseline to the post-test, completed 1 week after the intervention.

Table 2. Changes in Measures of Knowledge Comparing Baseline to The Post-Test Completed 1 Week After the Intervention

\begin{tabular}{lccl}
\hline \multirow{2}{*}{ knowledge } & Interventions & Control & \multirow{2}{*}{ P value } \\
\cline { 2 - 3 } & $\mathbf{( n = 3 6 )}$ & $\mathbf{( n = 3 6 )}$ & \\
\hline Pre test & & & \\
Mean (SD) & $-0.49(1.31)$ & $-0.57(1.49)$ & 0.823 \\
Median & -0.63 & -1.13 & \\
Range & 4.74 & 6.41 & \\
\hline Post test & & & \\
Mean (SD) & $1.23(1.17)$ & $-0.27(1.29)$ & 0.000 \\
Median & 0.99 & -0.65 & \\
Range & 5.91 & 6.03 & \\
\hline P value & 0.000 & 0.359 & \\
\hline
\end{tabular}

Based on the above table it is known that there is a significant difference in post test score between the treatment group and control group with $p$ value $<0.05$

Table 3. Changes In Measures of Attitude Comparing Baseline to The Post-Test Completed 1 Week After the Intervention

\begin{tabular}{lccl}
\hline \multirow{2}{*}{ Attitude } & Interventions & Control & \multirow{2}{*}{ P value } \\
\cline { 2 - 3 } Pre test & $\mathbf{n = 3 6}$ & $\mathbf{n = 3 6}$ & \\
Mean (SD) & $0.34(1.14)$ & $0.14(1.35)$ & 0.505 \\
Median & -0.05 & -0.16 & \\
Range & 3.61 & 6.74 & \\
\hline Post Test & & & \\
Mean (SD) & $1.07(1.38)$ & $0.24(1.59)$ & 0.022 \\
Median & 1.18 & -0.17 & \\
Range & 7.72 & 7.45 & \\
\hline P value & 0.022 & 0.771 & \\
\hline
\end{tabular}

There are differences in knowledge and attitude of women of childbearing age between the control group and treatment group with $p>$ 0.01 and $R R$ 3.5. This means that women of childbearing age who receive health education through cross-platform applications have a 3.5 times probability of knowledge and good attitude compared to women of childbearing age who are not getting health education through crossplatform applications. 
Table 4. Differences of Categorical of Knowledge and Attitude Comparing Baseline to The Post-Test Completed 1 Week After the Intervention

\begin{tabular}{|c|c|c|c|c|c|}
\hline \multirow{2}{*}{ Groups } & \multicolumn{2}{|c|}{ Knowledge and Attitude } & \multirow{2}{*}{ Total } & \multirow{2}{*}{$P$ value } & \multirow{2}{*}{$\mathrm{RR}^{*}(\mathrm{IK} 95 \%)$} \\
\hline & Low & Good & & & \\
\hline Control $(n=36)$ & $30(83,3 \%)$ & $6(16,7 \%)$ & $36(100 \%)$ & חمคח & 3,5 \\
\hline Interventions $(n=36)$ & $9(25 \%)$ & $27(75 \%)$ & $36(100 \%)$ & 0.000 & $(1.9-6.4)$ \\
\hline
\end{tabular}

\section{Discussion \\ Principal Findings}

With the advent of the HPV vaccine and the limitless screening possibilities that have been afforded by the growing understanding of HPV and the role that it plays in the evolution of cervical cancer, there is a real possibility that cervical cancer can be eliminated in the future. However, for that vision to become a reality there are numerous complexities that have to be resolved with regards to prevention as well as to screening for cervical cancer. The main key to empowerment is knowledge, behavioral skills, and personal responsibilities. For this reason, an increase in partnerships between patients and health workers is needed. (34) The innovative strides that have made been made at the present time must be met by global efforts that are tailored to various societal confines. Individuals that are at higher risk of acquiring cervical cancer are those that demonstrate less knowledge of HPV and the HPV vaccine.

Therefore, educational outreach and program funding is needed that are targeted at reaching the subgroups of the population with low health care literacy and who are at risk of succumbing to the morbidity and mortality of this preventable cancer. The call to local and governmental officials to enhance the educational outreach and program funding as a means to decrease the incidence of morbidity and deaths due to cervical cancer is also at the frontline of the dialogue in LMICs. Immunization of women with HPV vaccine to potentially prevent cervical cancer in these regions may take a back seat to other health care issues in light of the cost and the unique blend of genotypes that are present based on the geographical region. Fortunately, officials in these regions are becoming more knowledgeable of the advantages of implementing innovative cervical cancer see-and-treat programs (35).

The initial knowledge on the respondents of this study did not show a significant difference, $(p>$ $0.05)$. This study is in line with research Shakya, $\mathrm{S}$, et al that of 122 research subjects, only $6 \%$ of respondents have ever heard of cervical cancer. The basic knowledge of respondents about risk factors and symptoms of cervical cancer is very less. After the respondents attended the counseling, the proportion of women who wanted to participate in early detection increased from $15.6 \%$ to $100 \%$. Knowledge of cervical cancer in women in rural Nepal underscores the importance of general awareness about cervical cancer on a national scale. Community-based awareness programs can change the attitudes of women of childbearing age on early detection of cervical cancer, and women in these groups can play a major role in promoting participation in cervical cancer early detection programs (36).

Insufficient knowledge about the signs and symptoms of breast cancer might lead to poor performances of breast diagnostic checks. Knowledge about the symptoms of breast cancer appears to influence the participants' screening behavior. It can thus be concluded that knowledge is a basic component that may help the participants to perform breast cancer diagnostic checks for early breast cancer detection. Poorer knowledge regarding the identification of symptoms of breast cancer is associated with late detection and poor survival(37). 


\section{Limitations}

While the results of this study are very promising, there are some limitations. First, the sample size was relatively small and we used a quasi-experimental study design. Further research is needed to validate the effectiveness of the intervention with larger sample women using a rigorous research design, such as a randomized controlled trial. Second, our study was not designed to explore what would be the optimum time interval for program delivery. Limitations in this study that cannot be known how the aspect of satisfaction of perceptions and responses of respondents after getting health education through cross-platform messaging services so it needs to be supported by qualitative research.

\section{CONCLUSIONS AND RECOMMENDATIONS}

The results of this study can be concluded that there are differences in knowledge and attitude of women of childbearing age between the control group and treatment group with $p>$ 0.01 and RR 3.5. This means that women of childbearing age who receive health education through cross-platform applications have a 3.5 times probability of knowledge and good attitude compared to women of childbearing age who are not getting health education through cross-platform applications. This indicates that health education with cross-platform messaging services affect the knowledge and attitude of women of childbearing age about early detection of cervical cancer. Given emerging technological developments, effective interventions that could be adapted to efficiently disseminate culturally appropriate health information and promote positive health behavior changes would broadly impact the social determinants of health disparities in hard-to-reach, vulnerable populations.

Policy making (Dinas Kesehatan) can utilize cross-platform messaging application services on cellular telephones as an educational medium in order to support the development of Indonesian public health, with the intention not to be a means of communication that must function as a support for other health media. The results of this study can be used as a reference (model) of health education learning through information technology assistance that includes cross platform messaging applications that can be carried out by groups or related community institutions to deliver messages or health information.

\section{REFERENCES}

1. Torre L, Bray F, Siegel R, Ferlay J, Lortettieulent J, Jemal A. Global cancer statistics. CA Cancer J Clin. 2015;65(2):74-108.

2. Fitzmaurice $C$, Dicker D, Pain A, Hamavid H, Moradi-Lakeh M. Global Burden of Disease Cancer Collaboration, The Global Burden of Cancer 2013. JAMA Oncol. 2015;1(4):50527.

3. De Souza J, Hunt B, Asirwa F, Adebamowo C, Lopes G. Global health equity: cancer care outcome disparities in high-, middle-, and low-income countries. J Clin Oncol. 2016;6-13.

4. American Cancer Society. Global cancer facts and figures. 2nd ed. Atlanta; 2011. 1-57 p.

5. Sankaranarayanan R, Ramadas K, Qiao Y. Managing the changing burden of cancer in Asia doi:10.1186/1741-7015-12-3. BMC Med. 2014;12(1).

6. Persatuan Dokter Spesialis Patologi. Kanker di Indonesia tahun 2008: data histopatologik Indonesia. Jakarta: Yayasan Kanker Indonesia; 2012.

7. Bruni L, Albero G, Serrano B, Mena M, Gómez $D$, Muñoz J, et al. ICO/IARCInformation Centre on HPV and Cancer (HPV Information Centre). Human Papillomavirus and Related Diseases in Indonesia. Summary Report 2015-12-23. 2016. 
8. Camacho R, Sepúlveda C, Neves D, Piñeros $\mathrm{M}$, Villanueva $\mathrm{M}$, Dangou J, et al. Cancer control capacity in 50 low- and middleincome countries. Glob Public Health. 2015;10(9):1017-1031.

9. World Health Organization. Cancer Country Profiles. 2014;50:1-4.

10. Vet J, Kooijman J, Henderson F, Aziz F, Purwoto $G$, Susanto $H$, et al. Single-visit approach of cervical cancer screening: see and treat in Indonesia. $\mathrm{Br} \mathrm{J}$ Cancer. 2012;107(5):772-777.

11. Iskandarsyah A, de Klerk C, Suardi D, Soemitro M, Sadarjoen S, Passchier J. Psychosocial and cultural reasons for delay in seeking help and nonadherence to treatment in Indonesian women with breast cancer: a qualitative study. Heal Psychol. 2014;33(3):214-221.

12. Fitriyanti $D$, Mardiyono $M$, Bakhtiar $Y$. The Effectiveness of Cognitive Behavioral Therapy (CBT) To Decreased Depression in Woman Patients with Cancer included cervical cancer and breast cancer. J Ners dan Kebidanan Indones. 2019;6(3):27.

13. Kanchanachitra $C$, Lindelow $M$, Johnston T, Hanvoravongchai P, Lorenzo F, Huong $\mathrm{N}$. Human resources for health in southeast Asia: shortages, distributional challenges, and international trade in health services. Vol. 377, Lancet Publishing Group. 2011. 769-781 p.

14. Kohler R, Gopal S, Miller A, Lee C, Reeve $B$, Weiner B. A framework for improving early detection of breast cancer in subSaharan Africa: a qualitative study of helpseeking behaviors among Malawian women. doi:10.1016/j.pec.2016.08.012. Patient Educ Couns. 2017;100(1):167-173.

15. Almuammar A, Dryden C, Burr J. Factors associated with late presentation of cancer: a limited literature review. J Radiother Pract. 2010;9(2):117-123.
16. Buckle G, Collins J, Sumba P, Nakalema B, Omenah D, Stiffler K. Factors influencing time to diagnosis and initiation of treatment of endemic Burkitt lymphoma among children in Uganda and western Kenya: a cross-sectional survey. Infect Agent Cancer. 2013;8(1):36.

17. Brown C, Suneja G, Tapela N, Mapes A, Pusoentsi M, Mmalane M. Predictors of timely access of oncology services and advancedstage cancer in an HIV-endemic setting. Oncologist. 2016;21(6):731-738.

18. Patel BN. Chapter 3 Physiology of Pain Physiology of pain Central pain pathways e spinothalamic pathway and the trigeminal pathway. Seattle: IASP.; 2010. 13-17 p.

19. Mpunga T, Tapela N, Hedt-Gauthier B, Milner D, Nshimiyimana I, Muvugabigwi G. Diagnosis of cancer in rural Rwanda: early outcomes of a phased approach to implement anatomic pathology services in resource-limited settings. Am J Clin Pathol. 2014;142(4):541-545.

20. Handayani K, Sitaresmi M, Supriyadi E, Widjajanto P, Susilawati D, Njuguna F. Delays in diagnosis and treatment of childhood cancer in Indonesia. Pediatr Blood Cancer. 2016;63(12):2189-2196.

21. Solomon D, Schiffman M. Cervical Cancer Screening. In: Goldman, MB.; Hatch, MC., editors. Women and Health. Academic Press; 2000. 942-8 p.

22. Safaeian M, Solomon D, Castle PE. Cervical cancer prevention-cervical screening: science in evolution. Obstet Gynecol Clin North Am. 2007;34(4):739.

23. Globocan. The GLOBOCAN 2002 database. 2002;

24. Safaeian M, Kiddugavu M, Gravitt P. Comparability of self-collected vaginal swabs andphysician-collected cervical swabs for detection of human papillomavirus infections in Rakai,Uganda. Sex Transm Dis. 2007;34(7):429-436. 
25. Singh V, Sehgal A, Luthra U. Screening for cervical cancer by direct inspection. Br Med J. 1992;304(6826):534-535.

26. Denny L, Quinn M, Sankaranarayanan R. Chapter 8: Screening for cervical cancer in developing countries. Vaccine. 2006;24:S71S77.

27. Sankaranarayanan R, Gaffikin L, Jacob M, Sellors J, Robles S. A critical assessment of screeningmethods for cervical neoplasia. Int J Gynecol Obstet. 2005;89:S4-S12.

28. Jeronimo J, Schiffman M. Colposcopy at a crossroads. Am J Obs Gynecol. 2006;195:349-353.

29. Boonpongmanee $C$, Jittanoon P. Predictors of papanicolaoutesting in working women in Bangkok, Thailand. Cancer Nurs. 2007;30(5):384-389.

30. Bankhead C, Brett J, Bukach C. The impact ofscreening on future health-promoting behaviours andhealth beliefs: a systematic review.(Winchester, England);(): Health Technol Assess (Rockv). 2003;7(42):1-92.

31. Vlasta VJ, Thyra d. J, Ipek GU, RifatA, Josip C. Mobile phone messaging for preventive health care. Cochrane Database Syst Rev. 2012;45-54.
32. Khosravi M, Shafaee S, Karimi H, Haghollahi F, Ramazanzadeh F, Mamishi N. Validity and Reliability of the Knowledge, Attitude and Practice (KAP) Questionnaire about Cervical Cancer and its Screening among Iranian Women. Basic Clin Cancer Res. 2012;4(1):2-7.

33. Sumintono B, Widhiarso W. Aplikasi Model Rasch Untuk Penelitian IImu-IImu Sosial. Edisi Ke-2. Cimahi. Trim Komunikata Publishing House; 2015. 45-78 p.

34. Imelda F, Darti NA, Siregar FLS. Effect of Physical Exercise on Fatigue in Cervical Cancer Patients. J Ners dan Kebidanan Indones. 2019;7(1):41.

35. McGraw SL, Ferrante JM. Update on prevention and screening of cervical cancer. World J Clin Oncol. 2014;5(4):744-752.

36. Shakya S, Karmacharya B, Afset J, Bofin A, Åsvold B, Syversen U, et al. Community-Based Health Education has Positive Influence on The Attituce to Cervical Cancer Screening among Woman in Rural Nepal. J Cancer Educ. 2016;31(3):547-53.

37. Ramathuba, D. U., Ratshirumbi, C. T., \& Mashamba TM. Knowledge, attitudes and practices toward breast cancer screening in a rural South African community. Curationis. 2015;38(1):1172. 